\title{
KLASIFIKASI KOSAKATA PERMAINAN RAKYAT MELAYU SAMBAS: PENDEKATAN ETNOLINGUISTIK
}

\author{
Sabhan Rasyid, Sisilya Saman, Agus Syahrani \\ Program Studi Pendidikan Bahasa dan Sastra Indonesia FKIP Untan \\ Email:sabhan_rasyid@rocketmail.com
}

\begin{abstract}
Researcher in this study focuses on the observation of cultural object, that is folk games. The referred folk games are traditional games played by the local people. Acquisition of data conducted in the 19 subistrict of Sambas, West Kalimantan. Researcher uses qualitative research method, specifically by translating the vocabulary data of Malay folk games in the District of Sambas. This study also uses ethnolinguistic approach that views the relationship between language and cultural elements within Malay community in Sambas. Analysis conducted by researcher towards the collected data is the type of meaning analysis based on the classification of tools, techniques, player name, and the name of the folk game. By virtue of research, researcher accumulated 173 words as research data. All of data comprise of 30 kind of folk games with classification, that is 51 words as tools, 44 words as techniques, 4 words as player name, and 30 words as the name of the folk games classification.
\end{abstract}

Key word: Folk games, ethnolinguistic, computerized linguistics

\begin{abstract}
ABSTRAK
Penelitian ini memfokuskan pengamatan pada objek kebudayaan, yaitu permainan rakyat. Permainan rakyat yang dimaksud adalah permainan yang dimainkan oleh masyarakat yang sifatnya masih tradisional. Kegiatan pengambilan data dilakukan di 19 kecamatan yang ada di Kabupaten Sambas Kalimantan Barat. Peneliti menggunakan metode penelitian kualitatif, yaitu dengan menerjemahkan data kosakata permainan rakyat Melayu Kabupaten Sambas. Penelitian ini juga menggunakan pendekatan etnolinguistik yang memandang hubungan bahasa dengan unsur budaya di dalam masyarakat Melayu Sambas. Analisis yang dilakukan peneliti terhadap data yang dikumpulkan adalah analisis jenis makna berdasarkan klasifikasi alat, teknik, nama pemain, dan nama permainan rakyat. Berdasarkan penelitian yang dilakukan, peneliti berhasil menghimpun 173 kata sebagai data penelitian. Keseluruhan data tersebut didapatkan dari proses wawancara dan perekaman yang dilakukan peneliti selama meneliti di Kabupaten Sambas. Keseluruhan data tersebut terdiri atas 30 jenis permainan rakyat dengan klasifikasi, yaitu 51 kata berupa klasifikasi alat, 44 klasifikasi teknik, 4 klasifikasi nama pemain, dan 30 klasifikasi nama permainan.
\end{abstract}

Kata Kunci: Permainan rakyat, etnolinguistik, komputerisasi linguistik 


\section{PENDAHULUAN}

Permainan rakyat adalah suatu hal yang dilakukan masyarakat dalam rangka bermain di suatu daerah tertentu. Permainan rakyat memiliki klasifikasi berdasarkan tempat dan waktu bermain, serta jenis alat yang digunakan. Permainan rakyat sering dilakukan masyarakat sebagai sarana dalam membangun komunikasi untuk menjaga kerukunan masyarakat.

"Permainan rakyat sebagai satu di antara unsur kebudayaan bangsa perlu diselamatkan" (Yunus, 1980:7). Sebuah usaha yang nyata dalam menyelamatkan unsur kebudayaan, seperti permainan rakyat adalah dengan mengumpulkan data tentang permainan rakyat dan membukukannya sebagai bentuk pendokumentasian.

Penelitian terhadap objek yang berkaitan dengan kebudayaan merupakan kegiatan ilmiah yang sering dilakukan oleh banyak peneliti untuk menjaga kelestarian kebudayaan tertentu. Peneliti dalam kesempatan ini meneliti objek kebudayaan, yaitu permainan rakyat yang ada di Kabupaten Sambas, Kalimantan Barat. Alasan peneliti meneliti objek permainan rakyat ini karena permainan rakyat merupakan sesuatu yang berhubungan langsung dengan masyarakat yang saat ini sudah mulai kehilangan eksistensi di lingkungannya.

Permainan rakyat saat ini sudah semakin tersaingi oleh permainan-permainan elektronik modern. Permainan modern, seperti play station dan game boy dinilai masyarakat sebagai permainan yang aman bagi anak-anak. Kondisi seperti inilah yang membuat permainan rakyat yang sifatnya tradisional menjadi semakin terpinggirkan dari masyarakat.

Penelitian yang dilakukan peneliti adalah penelitian terhadap kosakata permainan rakyat. Alasan peneliti fokus pada kosakata karena kosakata merupakan unsur bahasa yang secara spesifik selalu muncul dalam permainan rakyat. Keseringan muncul bentuk kata daripada frasa dan klausa 
membuat peneliti lebih fokus pada kata dalam penelitian ini. Alasan lain, yaitu penelitian ini belum pernah dilakukan di Kabupaten Sambas dan objek penelitian ini masih jarang dilakukan dalam penelitian mahasiswa.

Permainan rakyat yang ada di Kabupaten Sambas sampai saat ini masih sangat beragam dan tersebar di berbagai tempat walaupun jumlah pemakainya sudah semakin berkurang. Dalam hal ini, peneliti mendata kosakata dari keberadaan permainan itu secara merata di seluruh kecamatan di Kabupaten Sambas. Maksud dari pemilihan semua wilayah ini, yaitu untuk menuntaskan pendataan permainan rakyat di Kabupaten Sambas sebelum hilang.

Penelitian terhadap kebudayaan masyarakat merupakan sebuah tindakan yang mengandung manfaat yang baik. Selain dapat menggali potensi lokal terhadap pemerkayaan bahasa daerah dan Indonesia, penelitian seperti ini juga dapat menjadi sebuah kegiatan yang baik bagi usaha pelestarian kebudayaan masyarakat di Kabupaten Sambas, Kalimantan Barat. Peneliti memperhatikan kosakata yang ada dalam permainan rakyat dengan karakteristik tertentu. Keseluruhan keberadaan kosakata tersebut dicatat dan disajikan oleh peneliti dengan utuh. Adapun kosakata tersebut dilihat dari jenis makna kosakata dengan klasifikasi alat, teknik, nama pemain, dan nama permainan berdasarkan jenis permainan rakyat Melayu Sambas.

Kosakata yang ada dalam permainan rakyat di Kabupaten Sambas sebagai contoh peneliti paparkan sebagai berikut. 
Tabel 1 Contoh Permainan

\begin{tabular}{llll}
\hline Kosakata & Fonetik & Makna Leksikal & Klasifikasi \\
\hline guli & guli & kelereng & alat \\
\hline tenjen & tenjen & $\begin{array}{l}\text { menaikkan posisi guli } \\
\text { dengan bantuan tanah }\end{array}$ & \\
& & yang tumpuk & \\
& & pemain yang & nama pemain \\
memiliki giliran & \\
buncik & buncik & terakhir melesatkan & \\
& & guli dalam permainan \\
& & gasing & nama permainan \\
\hline gasing & gasig & &
\end{tabular}

Penelitian ini dilakukan di Kabupaten

Sambas yang memiliki 19 kecamatan, yaitu

Kecamatan Sambas, Sebawi, Tebas,

Semparuk, Pemangkat, Salatiga, Selakau,

Selakau Timur, Tekarang, Jawai, Galing,

Jawai Selatan, Sajad, Sejangkung, Paloh,

Teluk Keramat, Tangaran, Subah, dan

Sajingan Besar. Penelitian di seluruh

kecamatan ini dilakukan di 19 desa yang dipilih berdasarkan kriteria yang ditentukan, yaitu pusat kegiatan budaya di kecamatan tertentu di Sambas berdasarkan nilai sejarah, pusat kegiatan masyarakat, dan imunitas suatu desa dalam mempertahankan tradisi masyarakatnya. Adapun desa yang menjadi lokasi penelitian, yaitu Tumuk Manggis, Tebing Batu, Tebas Kuala, Semparuk,
Harapan, Parit Baru, Parit Baru, Seranggam, Tekarang, Sentebang, Galing, Sabaran, Tengguli, Setalik, Tanah Hitam, Sekura, Semata, Sabung, dan Kaliau'.

Peneliti memfokuskan penelitian ini pada kosakata yang terkandung dalam permainan rakyat Melayu Sambas. Kosakata merupakan pembendaharaan kata. "Kata adalah satuan bahasa yang memiliki satu pengertian atau deretan huruf yang diapit oleh dua buah spasi dan mempunyai satu arti" (Chaer, 2007:163). Kata yang dimaksud peneliti dalam hal ini adalah kata-kata yang diklasifikasikan berupa alat, teknik, nama pemain, dan nama permainan.

Berdasarkan pemaparan tersebut, peneliti dalam penelitian ini memaparkan 
kata dalam permainan rakyat Melayu Sambas yang berupa alat, teknik, nama pemain, dan nama permainan dengan kajian makna leksikal. Makna leksikal yang dimaksud adalah makna yang terkandung dalam kata yang belum dikaitkan dalam konteks kalimat. Kridalaksana (dalam Pateda, 1996:119) mengungkapkan bahwa makna leksikal merupakan makna kata yang dipunyai unsurunsur bahasa lepas dari penggunaannya atau konteksnya.

\section{METODE PENELITIAN}

Metode yang dilakukan dalam penelitian ini adalah metode penelitian deskriptif. Jauhari (2007:35) mengungkapkan bahwa metode deskriptif merupakan metode penelitian yang memberikan gambaran atau uraian atas suatu keadaan dengan jelas tanpa ada perlakuan terhadap objek yang diteliti.

Sesuai dengan penjelasan di atas, peneliti berusaha untuk mendeskripsikan masalah penelitian ini, yaitu jenis makna kosakata permainan rakyat. Adapun bentuk penelitian yang digunakan dalam penelitian ini adalah kualitatif. Bentuk penelitian kualitatif menuntut peneliti untuk cermat dalam menyusun data hasil penelitian secara sistematis. Menurut Sugiyono (2012:15), metode kualitatif digunakan untuk mendapatkan data yang mendalam, suatu data yang mengandung makna.” Berdasarkan pendapat tersebut jelas sudah bahwa penelitian kualitatif harus disertai data yang cukup dan harus tersusun secara sistematis.

Pendekatan yang digunakan dalam penelitian ini adalah pendekatan etnolinguistik. Pendekatan ini melihat bahasa yang lahir dalam sebuah kebudayaan lokal masyarakat. Pendekatan ini diambil karena sesuai dengan objek penelitian yang akan dilakukan, yaitu permainan rakyat.

Pendekatan etnolinguistik ini memiliki tuntunan terhadap kinerja peneliti saat mengumpulkan data di lapangan. Menurut Sibarani (2004:51), "Metode pengumpulan yang digunakan dalam antropolinguistik 
adalah wawancara, observasi, dan kajian dokumen.”

Pendekatan etnolinguistik yang digunakan dalam penelitian ini juga cenderung mengikuti aliran etnografi berbicara. Etnografi berbicara menitikberatkan penelitian bahasa terhadap konteks budaya. "Etnografi berbicara berasumsi bahwa penutur, dengan maksud tertentu, menerapkan sumber linguistik untuk tujuan sosial dalam situasi yang ditentukan oleh budaya," (Palmer, 1996).

Data dari penelitian ini adalah kosakata yang terkandung dalam permainan rakyat di Kabupaten Sambas. Sumber data penelitian ini, yaitu masyarakat yang menjadi pelaku permainan rakyat sekaligus penutur kosakata yang ada dalam permainan rakyat dan informan yang mengetahui permainan rakyat di Kabupaten Sambas. Pelaksanaan penelitian dilakukan di 19 desa, yaitu Tumuk Manggis, Tebing Batu, Tebas Kuala, Semparuk, Harapan, Parit Baru, Parit Baru, Seranggam, Tekarang, Sentebang, Galing,
Sabaran, Tengguli, Setalik, Tanah Hitam, Sekura, Semata, Sabung, dan Kaliau'.Peneliti dalam penelitian ini berhasil mewawancarai 11 informan yang dianggap sudah mewakili Sambas secara keseluruhan. Kesebelas informan tersebut merupakan usulan masyarakat setempat karena digolongkan sebagai tokoh budaya Melayu Sambas.

Informan dalam penelitian ini dipilih berdasarkan kriteria tertentu. Menurut Samarin (1988:55- 62), "Syarat-syarat pemilihan informan, yaitu berusia di atas 30 tahun, memilih informan yang berjenis kelamin sama, mengetahui kebudayaan setempat dan penutur asli bahasa dan dialek yang diteliti."

Teknik yang dilakukan peneliti dalam mendapatkan data di lapangan adalah teknik perekaman dan wawancara. Teknik perekaman dilakukan menggunakan perekam visual pada masyarakat yang sedang melakukan permainan rakyat. Wawancara dilakukan kepada pemuka adat dan pelaku permainan rakyat terkait keberadaan 
permainan rakyat dan kosakata yang terkadung di dalamnya. Kegiatan wawancara dilakukan dengan bantuan instrumen tulis, gambar, dan alat perekam.

Alat pengumpul data yang digunakan dalam penelitian ini adalah instrumen wawancara, alat perekam video, dan perekam suara. Peneliti sebagai instrumen kunci, yaitu sebagai perencana, pelaksana, penganalisis, dan pelapor hasil penelitian. Adapun teknik analisis data yang dilakukan peneliti, yaitu mencatat kosakata berdasarkan hasil rekaman dan wawancara, mengklasifikasikan kosakata berdasarkan permainan rakyat, memberi makna terhadap kosakata berdasarkan data di lapangan, dan penarikan simpulan.

\section{HASIL DAN PEMBAHASAN}

\section{Hasil Penelitian}

Penelitian ini dilakukan di Kabupaten

Sambas yang memiliki 19 kecamatan, yaitu Sambas, Sebawi, Tebas, Semparuk, Pemangkat, Salatiga, Selakau, Selakau Timur, Tekarang, Jawai, Galing, Jawai
Selatan, Sajad, Sejangkung, Paloh, Teluk Keramat, Tangaran, Subah, dan Sajingan Besar. Peneliti memilih satu desa di setiap kecamatan yang ada. Adapun desa yang menjadi lokasi penelitian, yaitu Tumuk Manggis, Tebing Batu, Tebas Kuala, Semparuk, Harapan, Parit Baru, Parit Baru, Seranggam, Tekarang, Sentebang, Galing, Sabaran, Tengguli, Setalik, Tanah Hitam, Sekura, Semata, Sabung, dan Kaliau'.

Peneliti dalam penelitian ini berhasil mewawancarai 11 informan yang dianggap sudah mewakili Sambas secara keseluruhan. Kesebelas informan tersebut merupakan usulan masyarakat setempat karena digolongkan sebagai tokoh budaya Melayu Sambas. Sebelas informan tersebut, yaitu Wajidi Usman (Desa Sabaran), Rajali (Desa Sentebang), Haji Husin (Desa Semparuk Kuala), Durani (Desa Semparuk Kuala), Darmansyah (Desa Tebas Kuala), Aswandi (Desa Parit Baru), Rabuan Julkibli (Desa Seranggam), Nibanin Abdul Somad (Desa Tengguli), Haji Walid (Desa Sekura), Muin 
Ikram (Desa Tumuk Manggis), dan Haji Arpan (Desa Pendawan).

Penelitian yang dilakukan peneliti di Kabupaten Sambas menghasilkan data kosakata permainan rakyat berjumlah 173 kata. Keseluruhan data ini merupakan data yang didapatkan peneliti berdasarkan informasi dari informan dan pengalaman dari peneliti. Keseluruhan data ini kemudian dianalisis peneliti berdasarkan klasifikasi berupa alat, teknik, nama pemain, dan nama permainan.

Keseluruhan data kosakata yang diperoleh peneliti merupakan kata-kata yang terkandung dalam 30 jenis permainan yang berhasil peneliti kumpulkan dari lokasi penelitian. Seluruh jenis permainan rakyat tersebut yaitu, permainan [waw], [pal], [caykelilit], [seyalauwan], [sikopon], [sinatu], [conka?], [gasin], [sənimban], [sodar], [ti? sinamboy], [ruy ruy bare?], [pay pay sinabu], [poy poy alo?], [wak wak ampe?], [lambose], [jayka?], [senap:oran], [tum:a?], [payka?], [lag:um], [jijkal], [pantel], [par:ay-par:ayan], [tap:el], [sumpit], [lem lem ta?], [tutup mate], [tumpa? kar:a?], dan $\left[\right.$ panta $\left.^{\mathrm{y}}\right]$.

\section{PEMBAHASAN}

Keseluruhan data yang diperoleh peneliti, dianalisis berdasarkan klasifikasi yang berupa alat, teknik, nama pemain, dan nama permainan rakyat Melayu Sambas. Analisis tersebut dilengkapi dengan makna leksikal kosakata dalam permainan rakyat melayu Sambas. Hasil analisis kosakata permainan rakyat Melayu Sambas dipaparkan beberapa sebagai berikut.

\section{Analisis Kata Berupa Alat}

[waw] dalam pemahaman masyarakat dikenal dengan layang-layang. Pemaknaan dalam bahasa Indonesia juga layang-layang, yaitu sebuah alat yang umumnya terbuat dari bambu yang diraut dan dilengkapi dengan kertas.

[ban:ay] dalam pemahaman masyarakat dikenal dengan 'benang'. Pemaknaan masyarakat berkaitan dengan benang ini 
selalu dikaitkan dengan permainan layanglayang. Pemaknaan dalam bahasa Indonesia juga 'benang'.

[rayken] dalam pemahaman masyarakat dikenal dengan 'kerangka layang-layang'. [rayken] pada umumnya terbuat dari bambu yang diraut. [rayken] terdiri atas dua bagian, yaitu rangka lurus dan rangka lengkung. [rayken] dalam pemaknaan bahasa Indonesia, yaitu kerangka layang-layang.

[gal:as:an] dipahami masyarakat sebagai benang yang tajam dan khusus digunakan untuk bermain layang-layang. [gal:as:an] sepengetahuan informan merupakan benang plastik yang dibubuhi serbuk kaca dengan bantuan perekat dari kulit ikan pari yang direbus. [gal:as:an] dalam pemaknaan dalam bahasa Indonesia, yaitu gelasan.

[kul:okan] dipahami masyarakat sebagai alat yang terbuat dari kaleng susu bekas dan dipergunakan untuk menggulung benang layang-layang. [kul:okan] juga diungkapkan informan sebagai alat yang sampai saat ini sudah semakin beragam bahan pembuatannya, yaitu dari kayu dan paralon. Pemaknaan dalam bahasa Indonesia untuk [kul:okan] adalah gulungan; alat untuk menggulung benang biasa terbuat dari kaleng bekas, kayu, atau paralon.

[teraju] merupakan benang yang digunakan untuk menghubungkan benang dan layang-layang. [teraju] dibentuk sedemikian rupa untuk menimbang dan mengira-ngira terbangnya layang-layang. Pemaknaan [teraju] dalam bahasa Indonesia adalah benang dengan ukuran tertentu yang digunakan untuk menghubungkan benang dengan layangan biasanya dipola dengan bentuk segitiga.

[gal:as] merupakan kosakata yang maknanya sama dengan [gal:as:an]. Pemaknaan [gal:as] dalam bahasa Indonesia adalah gelasan; benang yang dibubuhi serbuk kaca dengan bantuan lem (kulit pari) atau lem pabrik.

[pəlastik] merupakan benang yang berbahan dasar plastik. Benang ini memiliki berbagai ukuran dan warna. Menurut 
informan, benang ini selalu diletakkan di bawah benang gelasan saat layang-layang diterbangkan. Pemaknaan [pəlastik] dalam bahasa Indonesia adalah benang yang berbahan dasar plastik; biasanya untuk bermain layang-layang

[waw kuton] merupakan satu di antara jenis atau model layang-layang. [waw kutoy] merupakan layang-layang yang tidak memiliki ekor. [waw kuton] berbentuk layang-layang seperti konsep matematika. Pemaknaan [waw kuton] dalam bahasa Indonesia adalah layang-layang tanpa ekor.

[waw rambai] merupakan layang-layang yang dilengkapi dengan ekor. [waw rambai] berbentuk layang-layang seperti konsep matematika dan dilengkapi dengan ekor yang biasanya terbuat dari pita kaset analog bekas. [waw rambai] dimainkan untuk tujuan unjuk keindahan di udara. Pemaknaan [waw rambai] dalam bahasa Indonesia adalah layang-layang menggunakan ekor, biasanya ekor terbuat dari pita kaset analog. [waw at:ong] merupakan layang-layang yang bentuk dan cara pembuatannya yang sangat sederhana. [waw at:ong] dibuat dari selembar kertas yang dilipat tiga dan dibuka sehingga menyerupai tong. Setelah dilipat, [waw at:ong] diberi tali dan siap diterbangkan. Pemaknaan [waw at:ong] dalam bahasa Indonesia adalah layang-layang dari kertas yang dilipat tiga; layang-layang tanpa kerangka.

[waw hias] merupakan satu jenis layanglayang yang bentuknya tidak seperti biasanya. [waw hias] biasanya berbentuk ikan atau burung dengan variasi warna yang beragam. [waw hias] sering dimainkan untuk unjuk keindahan bentuk dan warna. Pemaknaan [waw hias] dalam bahasa Indonesia adalah layang-layang hias; biasa berbentuk ikan atau burung dengan warna yang indah.

[waw pesen pare?] merupakan layanglayang yang berbentuk menyerupai ikan pari. Kata [pesen] dalam bahasa Melayu Sambas dekat artinya dengan fashion dalam bahasa 
Inggris yang artinya mode atau gaya. [waw pesen pare?] adalah layang-layang dengan mode atau gaya ikan pari. [waw pesen pare?] ini dimainkan untuk unjuk keindahan di udara. Pemaknaan [waw pesen pare?] dalam bahasa Indonesia adalah layang-layang dengan model ikan pari.

[gəlendon] merupakan alat yang digunakan untuk menggulung benang layangan. [gəlendon] ini dekat artinya dengan [kul:okan]. [gəlendon] biasanya terbuat dari kayu, paralon, atau kaleng susu bekas. Pemaknaan [gəlendon] dalam bahasa Indonesia adalah alat untuk menggulung benang (biasa terbuat dari kayu, canting, atau paralon).

[layko?] adalah bagian dari kerangka layang-layang biasa. Kerangka layang-layang terdiri atas dua bagian, yaitu kerangka lurus dan kerangka melengkung. [layko?] merupakan kerangka yang bentuknya melengkung. Pemaknaan [layko?] dalam bahasa Indonesia adalah bagian dari rangka layang-layang yang bentuknya melengkung. [waw petek] merupakan jenis layanglayang yang kerangkanya terbuat dari bambu tanpa bantuan benang. Seperti yang diketahui, layang-layang biasa memiliki kerangka yang terbuat dari bambu dan diikat dengan benang. Namun, [waw petek] ini hanya dibentuk dengan kerangka bambu yang dibentuk sedemikian rupa. Pemaknaan [waw petek] dalam bahasa Indonesia adalah layang-layang yang kerangkanya tidak menggunakan tali.

[waw rayken] merupakan layang-layang biasa yang berbentuk layang-layang seperti konsep matematika. [waw rayken] memiliki kerangka bambu yang diikat dengan benang. Penggunaan benang bertujuan menjaga kestabilan bentuk kerangka layang-layang. Pemaknaan [waw rayken] dalam bahasa Indonesia adalah layang-layang yang kerangkanya dilengkapi dengan benang.

[pal] merupakan alat yang terbuat dari kaca. Istilah [pal] digunakan masyarakat tidak hanya untuk benda yang terbuat dari kaca yang sekarang kita sebut kelereng atau 
gundu. Istilah [pal] juga diungkapkan masyarakat untuk menyebut biji karet dan gurah yang pada zaman dahulu digunakan sebagai pengganti kelereng. Pemaknaan [pal] dalam bahasa Indonesia adalah kelereng.

[guli] merupakan kata yang maknanya sama dengan [pal]. [guli] memiliki beragam jenis dilihat dari warnanya. [guli] terbuat dari kaca dengan ukuran yang beragam. Pemaknaan [guli] dalam bahasa Indonesia adalah kelereng.

[guc:u?] merupakan kelereng pilihan yang dipilih berdasarkan bentuk dan warnanya. Biasanya kelereng yang dipilih menjadi [guc:u?] adalah kelereng yang cocok di tangan dan warna serta bentuknya paling sempurna dibandingkan dengan kelereng lain. [guc:u?] merupakan kelereng inti yang tidak dipertaruhkan dalam permainan. Pemaknaan [guc:u?] dalam bahasa Indonesia adalah kelereng pilihan yang dijadikan kelereng inti (bukan taruhan).

[guli batu] merupakan jenis kelereng yang warnanya hitam pekat. [guli batu] ini termasuk kelereng yang jarang ditemui. [guli batu] juga sering digunakan sebagai [guc:u?]. Pemaknaan [guli batu] dalam bahasa Indonesia adalah kelereng yang seluruh bagiannya berwarna hitam pekat.

[guli gəlemben] merupakan kelereng biasa yang terbuat dari kaca. [guli gəlemben] dominan berwarna bening kaca dan di bagian tengahnya terdapat warna-warna yang kombinasinya menyerupai bentuk buah belimbing. Belimbing dalam bahasa Melayu Sambas adalah [gəlemben]. Oleh karena itu, kelereng tersebut dinamai masyarakat sebagai [guli gəlemben]. Pemaknaan [guli gəlemben] dalam bahasa Indonesia adalah kelereng yang berwarna bening dan bagian dalamnya terdapat warna-warna lain.

[guli susu] merupakan kelereng yang berwarna putih susu di seluruh bagiannya. [guli susu] sering dipilih untuk dijadikan [guc:u?] karena warnanya yang khas. Pemaknaan [guli susu] dalam bahasa Indonesia adalah kelereng yang seluruh bagiannya berwarna putih susu. 
[anak] merupakan alat yang digunakan untuk bermain [caykelilit]. [anak] merupakan istilah yang digunakan untuk kayu kecil yang digunakan untuk kelengkapan permainan [caykelilit]. Pemaknaan [anak] dalam bahasa Indonesia adalah kayu pendek yang digunakan dalam permainan [caykelilit].

[indo?] merupakan kayu yang berukuran agak panjang dibanding [anak]. [indo?] merupakan kata yang dalam bahasa seharihari masyarakat Melayu Sambas bermakna induk atau orang tua. Oleh karena itulah, kayu yang lebih panjang dalam permainan [caykelilit] dinamakan [indo?]. Pemaknaan [indo?] dalam bahasa Indonesia adalah kayu panjang yang digunakan dalam permainan [caykelilit].

[pancay] merupakan tiang yang dijadikan titik netral bagi pemain kejarkejaran untuk beristirahat dan tidak bisa dikejar. [pancan] bisa berupa tiang yang permanen, seperti tiang bendera, pagar, atau tiang jaring voli. Penentuan di mana [pancay] berada disepakati oleh semua pemain.
Pemaknaan [pancay] dalam bahasa Indonesia adalah tiang yang digunakan untuk tanda/titik aman pemain agar tidak bisa dikejar.

[buah] merupakan istilah untuk batu atau pecahan beling yang digunakan dalam permainan engkek-engkek. [buah] dapat digunakan oleh setiap pemain untuk melaksanakan permainan sampai akhir. [buah] dari setiap pemain tidak boleh bertukar. Pemaknaan [buah] dalam bahasa Indonesia adalah potongan/pecahan batu/beling yang digunakan untuk bermain engkek-engkek.

[gac:u?] merupakan kata yang maknanya sama dengan [buah]. [gac:u?] digunakan pemain dari awal sampai akhir dan tidak boleh tertukar. Pemaknaan [gac:u?] dalam bahasa Indonesia adalah potongan/pecahan batu/beling yang digunakan untuk bermain engkek-engkek.

[uras] merupakan alat yang termasuk penting dalam permainan [sinatu]. Dalam pemaknaan sehari-sehari masyarakat Melayu Sambas, [uras] bermakna sampah. Dalam 
permainan [sinatu], [uras] juga bermakna sampah, yaitu sampah yang hanyut di sungai, seperti plastik atau potongan kayu. [uras ] inilah yang dijadikan alat utama untuk ditebak oleh pemain lain. [uras] ini diletakkan di sela jari kaki dan harus ditebak oleh pemain lain. Pemaknaan [uras] dalam bahasa Indonesia adalah sampah.

[coyka?] merupakan alat yang digunakan untuk bermain congklak. [conka?] lazimnya berasal dari kulit kerang yang sudah kering. Namun, pada zaman sekarang sudah banyak diganti dengan biji kopi tiruan atau batu kecil. Pemaknaan [coyka?] dalam bahasa Indonesia adalah congklak.

[səgad:on] merupakan alat yang digunakan sebagai tempat menjalankan buah congklak/biji kopi. [səgad:on] pada zaman dahulu terbuat dari kayu yang dibentuk memiliki lubang-lubang setengah lingkaran yang berjumlah 16 lubang. Namun, zaman sekarang [səgad:on] sudah banyak yang diproduksi pabrik dengan bahan dasar plastik. Pemaknaan [səgad:on] dalam bahasa
Indonesia adalah alat untuk bermain congklak.

[gasin] merupakan alat yang tidak asing lagi didengar dan diketahui. [gasin] di Kabupaten Sambas terbuat dari bahan dasar kayu. Kayu yang dipilih merupakan kayu yang keras, seperti kayu baro dan kopi. [gasin] di Kabupaten Sambas memiliki keberagaman berdasarkan bentuk dan fungsinya. Pemaknaan [gasin] dalam bahasa Indonesia adalah gasing.

[tali gasin] merupakan alat kelengkapan permainan gasing. [tali gasin] memiliki panjang sekitar $1-2$ meter yang akan digulungkan ke gasing untuk diputarkan. [tali gasin] berbentuk panjang dengan ukuran ujung semakin kecil dari pangkalnya. [tali gasin] terbuat dari serat kulit kayu yang dijemur dan dipintal. Pamaknaan [tali gasin] dalam bahasa Indonesia adalah tali gasing.

[pəjedek] merupakan kayu pipih yang biasanya terbuat dari triplek. [pənedek] digunakan untuk mengangkat gasing yang sedang berputar untuk dinaikkan ke atas 
piring. [pəjedek] ini digunakan dalam permainan gasing [pərindu] atau menguri gasing. Pemaknaan [pənedek] dalam bahasa Indonesia adalah alat untuk mengangkat gasing yang berputar untuk diletakkan di atas piring.

[gasin leper] merupakan gasing dengan bentuk pipih dengan warna yang beragam. [gasin leper] digunakan pemain gasing biasanya untuk melakukan uri gasing atau mengadu lama putaran gasing. [gasin leper] ini sering digunakan anak-anak untuk bermain bersama sehari-hari di Sambas. Pemaknaan [gasin leper] dalam bahasa Indonesia adalah gasing pipih.

[buntut] merupakan alat kelengkapan yang melekat pada gasing. [buntut] dalam bahasa Melayu Sambas berarti ekor atau bagian paling bawah (pantat). [buntut] gasing berbentuk tajam, biasanya terbuat dari jarum bekas gramofon (peti musik). Pemaknaan [buntut] dalam bahasa Indonesia adalah bagian bawah gasing yang terbuat dari jarum gramofon. [gasin beker] merupakan gasing yang dibuat khusus untuk pangkah gasing. Pangkah gasing adalah kegiatan mengadu kekuatan gasing dengan cara satu pemain memangkah gasingnya ke gasing lawan yang sedang berputar. Pemaknaan [gasin beker] dalam bahasa Indonesia adalah gasing pemangkah.

[gasin bogo?] merupakan gasing yang didesain khusus untuk kegiatan menguri gasing. Menguri gasing ialah mengadu putaran gasing untuk menentukan gasing yang memiliki durasi putaran terlama. Pemaknaan [gasin bogo?] dalam bahasa Indonesia adalah gasing untuk menguri.

[gasin pinan] merupakan gasing yang ukurannya kecil karena berbahan dasar buah pinang. [gasin pinay] ini sering dimainkan oleh anak kecil. [gasin pinay] dibuat dari buah pinang tua yang sudah dikeringkan dan ditusuk dengan kayu kecil. Cara memainkan [gasin pinay] ini dengan cara diputar dengan tangan tanpa menggunakan tali gasing. Pemaknaan [gasin pinay] dalam bahasa 
Indonesia adalah gasing yang berbahan dasar buah pinang.

[gasin pərindu] merupakan gasing yang digunakan khusus untuk uri gasing. [gasin pərindu] ini dimainkan oleh orang-orang dewasa sebagai ajang adu ketahanan putaran gasing. Pemaknaan [gasin prindu] dalam bahasa Indonesia adalah gasing untuk menguri.

[gasin gərambay] merupakan istilah untuk gasing yang bentuknya pipih. [gasin gərambay] digunakan untuk kegiatan menguri gasing. Pemaknaan [gasin gərambay] dalam bahasa Indonesia adalah gasing pipih.

[gasin jantoy] merupakan istilah untuk gasing yang bentuknya gemuk dan bulat lonjong. [gasin janton] ini digunakan dalam kegiatan pangkah gasing. Kegiatan pangkah gasing dilakukan untuk melihat kekuatan gasing baik yang dipangkah, maupun yang memangkah. Pemaknaan [gasin jantoy ] dalam bahasa Indonesia adalah gasing bulat. [jayka?] merupakan alat sekaligus nama permainan yang berbahan dasar bambu. Pada umumnya alat ini terbuat dari bambu yang dibuat sepasang karena untuk dipijak. [janka?] juga bisa terbuat dari tempurung dan kaleng susu bekas. Pemaknaan [janka?] dalam bahasa Indonesia adalah egrang.

[kaki antu] merupakan istilah yang maknanya sama dengan [jayka?]. [kaki antu] juga berbahan dasar bambu, tempurung, atau keleng susu bekas. Alat ini dinamakan [kaki antu] karena saat digunakan, kaki penggunanya tidak mengenai tanah mirip seperti hantu yang diceritakan orang-orang tua. Pemaknaan [kaki antu] dalam bahasa Indonesia adalah egrang.

\section{Analisis Kata Berupa Teknik}

Permainan rakyat di Kabupaten Sambas yang tersebar di 19 kecamatan dari Selakau sampai Sajingan Besar memiliki beragam kosakata. Di antara beragamnya kosakata yang terdapat dalam permainan tersebut adalah kosakata yang tergolong teknik 
permainan. Pada bagian ini akan dipaparkan analisis makna dari kosakata permainan rakyat berdasarkan teknik permainan. Pemaknaan ini berdasarkan paham masyarakat yang didapat peneliti dari hasil penelitian lapangan dan pemaknaan dalam bahasa Indonesia.

Peneliti memaparkan kosakata yang tergolong sebagai teknik dalam permainan rakyat Melayu Sambas. Data kosakata teknik permainan berkelas kata verba. Berikut beberapa data kosakata teknik permainan beserta hasil analisis pemaknaannya.

[narik] merupakan teknik yang digunakan dalam permain [waw]. [narik] dimaknai masyarakat sebagai tindakan menarik benang layang-layang dengan tujuan tertentu. Pemain layang-layang akan menggunakan teknik [narik] untuk menurunkan layangan atau merendahkan posisi layang-layang atau mempertahankan kekuatan benang saat beradu benang dengan pihak lain. Pemaknaan [narik] dalam bahasa Indonesia adalah menarik benang layang- layang yang sedang dimainkan; biasanya untuk menurunkan layang-layang.

[yul:or] merupakan teknik mengendurkan atau memperjauh posisi layang-layang di udara. [yul:or] dilakukan dengan cara menyesuaikan panjang benang yang dimiliki. Teknik [yul:or] juga dapat dilakukan untuk memutuskan benang pemain lawan saat beradu benang layang-layang di udara. Pemaknaan [yul:or] dalam bahasa Indonesia adalah mengendurkan tali layanglayang untuk meninggikan posisi layanglayang di angkasa.

[gele?] merupakan teknik memutarmutarkan layang-layang di udara. Teknik [gele?] dilakukan pemain untuk mendapatkan benang dan layang-layang yang sudah putus di udara. Pemain layang-layang biasanya bisa menggandeng layang-layang lain yang sudah putus di udara dengan teknik [gele?]. Pemaknaan [gele?] dalam bahasa Indonesia adalah memutar-mutarkan posisi layanglayang; biasanya untuk memaut layanglayang lain yang benangnya sudah putus. 
[ambor] merupakan teknik menuju benang pemain lain. Pemain yang menggendurkan benang layangan dengan melakukan teknik [timpa?] biasanya pemain cepat. Teknik [ambor] ini dilakukan pemain untuk memutuskan benang layang-layang pemain lain saat beradu di udara. Pemain yang cekatan melakukan teknik [ambor] ini dimungkinkan dapat memenangkan peraduan benang layang-layang di udara. Pemaknaan [ambor] dalam bahasa Indonesia adalah mengendurkan tali layang-layang dengan cepat; biasanya dilakukan saat beradu.

[saok] merupakan kegiatan mengadu benang layang-layang di udara. [saok] dapat dilakukan pemain dengan sengaja maupun tidak disengaja. Hal ini terjadi karena keinginan pemain ingin mengadu benangnya atau ketidaksengajaan bertemunya benang layang-layang di udara. Pada orang tertentu, kegiatan [saok] dilakukan dengan taruhan barang atau uang. Pemaknaan [saok] dalam bahasa Indonesia adalah beradu benang layang-layang di udara.

[timpa?] merupakan kegiatan mengarahkan benang layang-layang kita 
muncul dalam permainan [pal]. Pemain yang mendapat giliran terakhir berdasarkan hasil [osom] mendapat julukan [buncik]. Pemaknaan [buncik] dalam bahasa Indonesia adalah pemain yang memiliki kesempatan terakhir untuk melontarkan kelereng.

[jadi] merupakan sebutan untuk pemain yang menjadi petugas mengejar atau mencari seseorang. Kosakata [jadi] muncul pada beberapa permainan, seperti [senap:oran] dan [seyalauwan]. Pemaknaan [jadi] dalam bahasa Indonesia adalah orang yang bertugas mengejar pemain lain; orang yang bertugas mencari pemain lain pada permainan petak umpet.

[njar:ok] merupakan sebutan untuk pemain yang secara terus menerus menjadi pemain yang mengejar dalam permainan kejar-kejaran. Pemain yang disebut [njar:ok] biasanya pemain yang memiliki fisik lemah sehingga tidak pernah memenangkan permainan. Pemaknaan [njar:ok] dalam bahasa Indonesia adalah orang yang selalu bertugas mengejar tanpa pernah digantikan orang lain.

[pəmanka?] merupakan sebutan untuk orang yang memangkah gasing. Pemain gasing yang bertugas sebagai [pəmayka?] adalah pemain yang memiliki keyakinan penuh tentang kualitas gasing. Pemaknaan [pəmayka?] dalam bahasa Indonesia adalah orang yang memukul gasing lawan dengan putaran gasing; pemangkah.

\section{Analisis Kata Berupa Nama Permainan}

Data kosakata permainan rakyat yang peneliti dapat dari penelitian lapangan terdiri atas kategori yang umum, yaitu nama permainan. Nama-nama permainan rakyat yang ada di Kabupaten Sambas dianalisis dan dimaknai berdasarkan pemahaman masyarakat dan bahasa Indonesia sebagai berikut.

[waw] merupakan nama permainan yang sekaligus menjadi nama alat yang dimainkan. Masyarakat Melayu Sambas memahami [waw] sebagai layang-layang yang memiliki beragam bentuk dan warna. Pemaknaan 
[waw] dalam bahasa Indonesia adalah layang-layang.

[pal] merupakan permainan yang menggunakan alat utama, yaitu kelereng. [pal] memiliki beragam jenis sub permainan, seperti [les], [kul:ok], [golo?], [apolo], dan [tat: $\left.{ }^{\mathrm{y}}\right]$. Pemaknaan [pal] dalam bahasa Indonesia adalah kelereng.

[caykelilit] merupakan permainan yang menggunakan sebuah lubang dan dua buah kayu dengan ukuran berbeda. [cankelilit] bisa dimainkan oleh dua pemain atau lebih. Pemaknaan [cankelilit] dalam bahasa Indonesia adalah jenis permainan rakyat Melayu Sambas yang menggunakan dua buah kayu (panjang dan pendek).

[senalauwan] merupakan permainan tanpa alat banyak dan bisa melibatkan banyak pemain. Masyarakat memahami permainan [senalauwan] sebagai permainan kejarkejaran dan dianggap sebagai olahraga. Pemaknaan [senalauwan] dalam bahasa Indonesia adalah kejar-kejaran. [sənajar:an] merupakan istilah yang maknanya sama dengan [seyalauwan]. Pemain memiliki kesempatan mengerjar dan dikejar dalam permainan yang tidak membutuhkan banyak alat ini. Pemaknaan [sənajar:an] dalam bahasa Indonesia adalah kejar-kejaran.

[sənalauwan cantiy] merupakan sub permainan [senalauwan]. Seorang pemain dituntut untuk mengejar pemain lain. Ciri khas permainan [səyalauwan cantin] adalah pemain yang bertugas mengejar harus menjaga menara canting yang disusun agar tidak dihancurkan oleh pemain lain. Pemaknaan [səyalauwan cantin] dalam bahasa Indonesia adalah kejar-kejaran menggunakan canting yang disusun dan ditendang.

[səyalauwan ae?] adalah sub permainan [sənalauwan]. Ciri khas dari permainan [səyalauwan ae?] adalah kegiatan kejarkejaran dilakukan di air. Permainan [sənalauwan ae?] sering dilakukan anak-anak Melayu Sambas ketika mandi di sungai sore 
hari. Pemaknaan [səyalauwan ae?] dalam bahasa Indonesia adalah kejar-kejaran di air. [səyalauwan bulan] merupakan sub permainan [səyalauwan]. Permainan [səyalauwan bulan] dilakukan pemain dengan cara melukis sebuah lingkaran di tanah yang dianggap sebagai bulan. Pemain yang bertugas mengejar harus memegang pemain lain dari luar lingkaran. Pemaknaan [səyalauwan bulan] dalam bahasa Indonesia adalah kejar-kejaran di dalam lingkaran bulan yang dilukis di tanah.

[sikopon] merupakan permainan yang menggunakan lukisan di tanah dengan bentuk kotak-kotak dan pemain harus melangkah melewati kotak-kotak tersebut. Permainan sikopon dimainkan oleh anak-anak Melayu Sambas baik pria, maupun wanita. Pemaknaan [sikopon] dalam bahasa Indonesia adalah engkek-engkek.

[tet tet brak] merupakan permainan yang sama dengan permainan [sikopon]. [tet tet brak] dipahami masyarakat berasal dari kata [tet tet] dan [brak]. [tet tet] artinya melangkah dengan satu kaki dan ucapan [brak] untuk kegiatan melangkahkan dua kaki di kotak yang telah dilukis. Pemaknaan [tet tet brak] dalam bahasa Indonesia adalah engkekengkek.

[sinatu] merupakan permainan yang dilakukan di air. [sijatu] dimainkan oleh anak-anak yang sedang mandi di sungai dengan kegiatan menebak sebuah barang yang disembunyikan di sela jari kaki. Seorang pemain harus menebak benda yang disembunyikan di sela jari kaki. Pemaknaan [sinatu] dalam bahasa Indonesia adalah permainan menebak barang sambil berenang. [conka?] merupakan permainan dengan menggunakan cangkang kerang dan sebuah wadah yang disebut [gəlendon]. Permainan [conka?] sering dimainkan oleh wanita di dalam rumah. Pemaknaan [conka?] dalam bahasa Indonesia adalah congklak.

[gasin] merupakan permainan yang menggunakan alat yang juga bernama [gasin]. [gasin] memiliki berbagai sistem permainan, seperti [manka?] dan [bərindu]. 
Permainan [gasin] lazimnya dilakukan oleh pria. Pemaknaan [gasin] dalam bahasa Indonesia adalah gasing.

[sənimban] merupakan permainan di dalam rumah dengan menggunakan batu atau cangkang kerang. Pemain harus menampi batu atau cangkang kerang untuk dijadikan penghitungan poin permainan. Pemaknaan [sənimban] dalam bahasa Indonesia adalah buah lima.

[sodar] merupakan permainan yang dilakukan secara berkelompok. Permainan [sodar] dilakukan oleh dua kelompok yang saling bersaing dalam mengumpulkan poin dengan cara harus melewati hadangan dari kelompok yang menjaga. Pemaknaan [sodar] dalam bahasa Indonesia adalah galah hadang.

[ti? sinambon] merupakan permainan di dalam rumah yang dilakukan dengan santai. Permainan [ti? sinamboy] dimainkan sambil menyanyikan lagu tertentu. Lagu yang dinyanyi berbunyi ti' sinambong, tikam si ari sannen, anak anak kemane die, kaling papat sitok die, ngambek aek di gunong pancau, cabut paddang sebilah sorang, belitong inong-inong, belitong inong-inong. Pemaknaan [ti? sinambon] dalam bahasa Indonesia adalah permainan di rumah dengan cara menadahkan tangan dan diiringi lagu.

[ruy ruy bare?] merupakan permainan di dalam rumah yang dilakukan secara berpasangan. Permainan ini dilakukan untuk mengisi waktu luang dan menghibur hati. Pemaknaan [ruy ruy bare?] dalam bahasa Indonesia adalah permainan di rumah secara berpasangan untuk menghibur hati.

[pay pay sinabu] merupakan permainan yang dilakukan oleh anak-anak sambil menyanyi. Lagu yang dinyanyikan berbunyi pang pang sinabu, kuale sawi, ujan bunut malikatan, sintak pallok siballah. Pemaknaan [pay pay sinabu] dalam bahasa Indonesia adalah permainan di rumah dengan meletakkan tangan di lantai dan berhadaphadapan diiringi lagu.

[pon pon alo?] merupakan permainan yang dilakukan oleh anak-anak sambil menyanyi. Lagu yang dinyanyikan berbunyi 
pong pong alok, alok simari tiong. Pemaknaan [poy poy alo?] dalam bahasa Indonesia adalah permainan di rumah dengan menumpuk tangan yang digenggam dan diringi lagu.

[wak wak ampe?] merupakan permainan yang dilakukan oleh anak-anak sambil menyanyi. Lagu yang dinyanyikan berbunyi wak wak ampek, ampek simari tiong, peluak palak nasek, lauk palak tengkuyong, kan ape beliong kan nabang aor, kan ape aor kan jullok bulan, kan ape bulan, kan maingan sannong. Pemaknaan [wak wak ampe?] dalam bahasa Indonesia adalah permainan di rumah dengan cara membujurkan kaki berhadapan dengan kawan diiringi lagu.

[lambose] merupakan permainan yang menggunakan alat utama, yaitu tali. Permainan lambose memiliki berbagai gerakan yang disesuaikan dengan tingkat kerumitan permainan. Pemaknaan [lambose] dalam bahasa Indonesia adalah main tali (gelang karet yang disambungkan sehingga panjang seperti tali). [jayka?] merupakan permainan yang menggunakan alat yang terbuat dari bambu, canting, ataupun tempurung. Permainan [jayka?] bersifat kompetitif seperti lomba lari. Pemain yang sampai pada garis akhir terlebih dahulu adalah pemenang. Pemaknaan [janka?] dalam bahasa Indonesia adalah egrang.

[senap:oran] merupakan permainan yang melibatkan banyak pemain. Permainan [senap:oran] dilakukan pada siang atau sore hari. Pemaknaan [senap:oran] dalam bahasa Indonesia adalah petak umpet.

[tum:a?] merupakan permainan pengantar tidur. Permainan [tum:a?] sering dilakukan anak-anak yang akan tidur bersama di sebuah rumah. Permainan ini menuntut ketelitian pemainnya karena harus menebak pemain lain yang seluruh tubuh pemain ditutup dengan kain sarung. Pemaknaan [tum:a?] dalam bahasa Indonesia adalah permainan menebak teman yang berada di dalam kain sarung denga cara meraba bagian 
tubuhnya (permainan dilakukan oleh anakanak berjenis kelamin sama).

[papka?] merupakan permainan mengadu dua buah benda dengan cara dibenturkan dengan keras. Permainan [payka?] dilakukan dengan perlengkapan biji karet atau biji gurah. Pemaknaan [panka?] dalam bahasa Indonesia adalah pangkah.

[lag:um] merupakan permainan yang menggunakan alat yang juga bernama [lag:um]. Masyarakat Sambas memainkan [lag:um] sering pada bulan Ramadhan karena dapat mengasyikkan sambil menunggu buka atau meramaikan malam. Pemaknaan [lag:um] dalam bahasa Indonesia adalah meriam bambu.

[jinkal] adalah permainan yang dilakukan tanpa alat. Permainan [jinkal] dapat dilakukan berdua atau lebih. Pemain harus melompati tangan yang dijengkal dan disusun secara vertikal. Semakin lama, ketinggian tangan yang harus dilompati akan semakin tinggi. Pemaknaan [jinkal] dalam bahasa Indonesia adalah permainan menggunakan tangan yang dijengkal ke atas dan dilompati oleh pemain lain.

[pantel] merupakan permainan yang menggunakan buah pinang yang sudah tua. Pemain harus menyusun buah pinang taruhan disuatu posisi. Pemain membuat garis yang berfungsi sebagai batas untuk melempar. Pemain akan melempar satu buah pinang menuju ke pinang taruhan. Pinang taruhan yang terkena lemparan akan menjadi hak milik pemain yang berhasil melempar. Pemaknaan [pantel] dalam bahasa Indonesia adalah permainan menggunakan buah pinang yang disusun dan dibidik menggunakan buah pinang.

[par:ay-par:anan] merupakan permainan menyerupai kegiatan perang para militer. Permainan ini lazim dilakukan oleh anak lakilaki. Pemain menggunakan pelepah pisang dan kayu sebagai senjata tiruan. Pemaknaan [par:an-par:ayan] dalam bahasa Indonesia adalah perang-perangan.

[tap:el] merupakan nama untuk permainan yang menggunakan alat bernama 
[tap:el]. Permainan [tap:el] sering dimainkan oleh anak laki-laki untuk mengisi waktu di sore hari. Pemaknaan [tap:el] dalam bahasa Indonesia adalah bermain katapel.

[sumpit] merupakan nama untuk permainan yang menggunakan alat bernama [sumpit]. Permainan [tap:el] sering dimainkan oleh anak laki-laki untuk mengisi waktu di sore hari. Pemaknaan [sumpit] dalam bahasa Indonesia adalah permainan dengan menggunakan alat bambu untuk meniupkan peluru (kacang hijau atau biji bunga jarum).

[lem-lem ta?] merupakan permainan yang dilakukan oleh anak-anak sambil menyanyi. Satu orang pemain harus ditutup matanya karena dianggap sebagai orang yang buta. Lagu yang dinyanyikan berbunyi lem lem tak, aji mahmud, sallem buta', kerundong sammut. Pemaknaan [lem-lem ta?] dalam bahasa Indonesia adalah permainan melayu sambas dengan cara menebak teman dengan mata ditutup kain dan diringi lagu tertentu. [tutup mate] merupakan permainan yang dilakukan oleh anak-anak sambil menyanyi. Satu orang pemain harus ditutup matanya karena dianggap sebagai orang yang buta. Lagu yang dinyanyikan berbunyi hai kawan pakai tutup mate, sana sini ku mencari tempat, siapa dapat jangan melompat. Pemaknaan [tutup mate] dalam bahasa Indonesia adalah permainan menebak teman dengan cara penebak ditutup matanya dan harus menebak teman dengan cara meraba anggota tubuh (rambut dan wajah) dan diiringi lagu tertentu.

[tumpa? kar:a?] merupakan permainan yang menggunakan alat gelang karet. Gelang karet yang menjadi taruhan harus disusun di suatu posisi. Pemain harus melemparkan gelang karet yang lain untuk menimpa karet gelang yang disusun. Karet gelang taruhan yang berhasil ditimpa akan menjadi hak milik pemain yang telah berhasil melempar. Pemaknaan [tumpa? kar:a?] dalam bahasa Indonesia adalah permainan menggunakan 
gelang karet yang dilemparkan menuju kumpulan karet gelang di posisi tertentu.

[panta $\left.{ }^{\mathrm{y}}\right]$ merupakan permainan yang menggunakan gelang karet. Pemain harus merentangkan satu gelang karet untuk ditujukan ke satu objek yang telah disepakati bersama. Pemaknaan $\left[p^{2} \operatorname{ta}^{\mathrm{y}}\right]$ dalam bahasa Indonesia adalah permainan menggunakan gelang karet yang diregangkan dan ditujukan ke sebuah objek.

\section{SIMPULAN DAN SARAN}

\section{Simpulan}

Data kosakata permainan rakyat yang telah dihimpun dari pelaksanaan penelitian lapangan dianalisis berdasarkan permasalahan yang telah ditetapkan. Pada pembahasan ini telah dianalisis jenis makna kosakata berdasarkan alat, teknik, nama pemain, dan nama permainan. Hasil analisis tersebut berisi uraian pengertian berdasarkan pemahaman masyarakat yang diketahui peneliti dari informan dan kegiatan masyarakat Melayu Sambas. Pemaknaan semua kosakata tersebut juga dilakukan dalam bahasa Indonesia sehingga pembaca akan dipermudah untuk mengerti makna dari kosakata permainan rakyat Melayu Sambas.

Saran

Kajian kosakata permainan rakyat Melayu Sambas merupakan kajian yang sangat menarik dan kaya analisis. Oleh karena itu, peneliti menyarankan beberapa hal berikut: (1) peneliti mengharapkan penelitian selanjutnya dapat meneruskan kajian peneliti agar penelitian kebudayaan yang berkaitan dengan linguistik dapat semakin banyak, peneliti selanjutnya yang tertarik mengkaji kosakata permainan rakyat dapat meneruskan data permainan yang telah dihimpun peneliti dan (2) peneliti menyarankan agar mengkaji kosakata permainan rakyat dalam analisis siktaksis. Alasan peneliti menyarankan demikian adalah kosakata permainan rakyat Melayu Sambas memiliki berbagai keunikan yang sangat bagus jika dikaitkan dalam analisis penggunaan kalimat. 


\section{DAFTAR RUJUKAN}

Samarin, William J. 1988. Ilmu Bahasa

Lapangan. Yogyakarta: Kanisius.

Palmer, Gary B. 1996. Toward a Theory of Cultural Linguistics. Texas: University of Texas Press.

Sibarani, Robert. 2004. Antropolinguistik.

Medan: Penerbit PODA.

Sugiyono. 2012. Metode Penelitian Kualitatif. Bandung: Alfabeta Bandung.

Jauhari, Heri. 2007. "Pedoman Penulisan Karya Ilmiah”. Bandung: Pustaka Setia.

Chaer, Abdul. 2007. Linguistik Umum. Jakarta: Rineka Cipta.

Pateda, Mansoer. 1996. Semantik Leksikal.

Jakarta: Rineka Cipta.

Yunus, Ahmad. 1980. Permainan Rakyat

Daerah Kalimantan Barat. Pontianak. 